ARTYKULY

Forum Pedagogiczne UKSW

$2 / 2012$

\title{
PÁDRAIG HOGAN
}

National University of Ireland

Maynooth (Irlandia)

\section{NAUCZANIE I UCZENIE SIE JAKO SPOSÓB ŻYCIA ${ }^{1}$}

\section{Streszczenie}

W tym artykule próbujemy ukazać, w jaki sposób należy rozumieć nauczanie i uczenie się - nie jako przedsięwzięcie narzucone $\mathrm{z}$ góry wolą władzy czy grupy, lecz jako sposób życia posiadający własną integralność, wypływający z wewnętrznej motywacji. Artykuł ma na celu przedstawienie takiego podejścia do praktyki i myśli wychowawczej, które w kluczowych punktach różni się od koncepcji Alasdair'a MacIntyre'a, choć równocześnie zawiera ważne podobieństwa. W dużej mierze zapomniany współcześnie Sokrates z Aten jest autorem oryginalnych inspiracji, ważnych dla rozumienia istoty wychowania, które będa przedmiotem analiz na początku tego artykułu. Następnie omawiamy niektóre wpływowe negacje tego rozumienia (nowoczesne i ponowoczesne). $\mathrm{Z}$ owych badań nad nauczaniem i uczeniem się jako szczególnym rodzajem relacji wynika konkluzja, w której naszkicowane zostają pokrótce pewne cnoty, konstytuujące ten sposób życia w jego bardziej aktywnych i bardziej refleksyjnych aspektach.

Słowa kluczowe: pedeutologia, filozofia edukacji, liberalizm.

${ }^{1}$ [Źródło: „Journal of Philosophy of Education” 37(2003)2, s. 207-223. Uwagi zamieszczone w nawiasach kwadratowych pochodzą od thumacza. Przyp. M.M.]. 


\section{Wprowadzenie}

Studia nad historią edukacji zachodniej pokazują, że nauczanie jako zawód rzadko cieszyło się wolnością uprawiania tej dyscypliny zgodnie z wizją nauczyciela ${ }^{2}$. Stąd, po wielu wiekach patriarchalnej kontroli nad nauczaniem i uczeniem się, pojawienie się liberalnego uniwersytetu w Niemczech na początku XIX wieku oznaczało przełom i nadejście tego, co później nazwano oświeceniowym ideałem wolności akademickiej. Ten ideał, który tak naprawdę ma korzenie starsze niż europejskie oświecenie, do niedawna wywierał dominujący wpływ na szkolnictwo wyższe na całym świecie. Lecz w zmienionej formie (podkreślając niezależność myśli i zdolności krytyczne każdego ucznia) ideał ten wpływał również na myślenie i praktykę wychowawczą w szkolnictwie podstawowym i ponadpodstawowym przez znaczną część XX wieku. Wychowawcze ideały oświeceniowe miały jednak przeciwników. W naszych czasach jednym z najbardziej zagorzałych był Alasdair MacIntyre - przynajmniej tak wynika z większości jego publikacji, oprócz być może tej jednej, Dependent Rational Animals z 1999 roku. Według MacIntyre’a ,projekt oświeceniowy” był błędem, czemu dał wyraz w wydanej po raz pierwszy w 1981 roku słynnej książce After Virtue [Dziedzictwo cnoty]. Przejawy tego poglądu odnajdujemy w wielu innych jego pismach takich, jak The Idea of an Educated Public ${ }^{3}$ (w końcowych rozdziałach książki Whose Justice? Which Rationality ${ }^{4}$ ) oraz Three Ri-

\footnotetext{
${ }^{2}$ Przez większą część historii Zachodu Kościół chrześcijański, a potem poszczególne denominacje religijne były stróżami i kustoszami, którzy zabiegali o jednolitość tego, w co należało wierzyć i czego nauczać. Jak to ujęli W. Boyd i E.J. King: „Klerykalny monopol na edukację powstały w okresie przejściowym między starożytnością a nowoczesnością i przetrwał ponad tysiąc lat, a jego oddziaływanie na życie intelektualne Europy było ogromne. Najbardziej oczywistym rezultatem tego było zasadnicze ograniczenie nauczania w ramach zakreślonych przez interesy i doktrynę Kościoła” (W. Boyd, E.J. King, The History of Western Education, Adam \& Charles Black, London 1966, s. 101). Błędem byłoby jednakże wnioskować z tego, że Kościół pełnił tu wyłącznie szkodliwą rolę.

3 Por. A.C. MacIntyre, The Idea of an Educated Public, [w:] Education and Values: The Richard Peters Lectures, red. G. Haydon, University of London Institute of Education, London1987.

${ }^{4}$ Por. A.C. MacIntyre, Whose Justice? Which Rationality?, Duckworth, London 1988. [Wydanie polskie: Czyja sprawiedliwość? Czyja racjonalność?, tłum. A. Chmie-
} 
val Versions of Moral Enquiry, a także w artykule Aquinas Critique of Education: Against his Own Age, Against Ours ${ }^{6}$.

Bardziej współcześnie MacIntyre wyraził swoje tezy na temat wychowania jako przedsięwzięcia ludzkiego w wywiadzie z Joseph'em Dunne w niniejszym czasopiśmie ${ }^{7}$. Spośród najbardziej rzucających się w oczy w tym wywiadzie twierdzeń MacIntyre'a warto wymienić cztery: po pierwsze, nauczanie samo w sobie nie jest działaniem praktycznym ${ }^{8}$, po drugie, życie nauczyciela nie jest jakimś szczególnym stylem życia, po trzecie, nauczanie nie jest nigdy niczym więcej niż środkiem do celu i w końcu po czwarte, filozofia wychowania nie jest odrębną dziedziną poszukiwań filozoficznych ${ }^{9}$. Tego rodzaju twierdzenia nie mogą nie zabrzmieć niepokojąco dla każdego nauczyciela, dla którego nauczanie jest czymś więcej niż tylko przypadkowym czy okazjonalnym zajęciem, i który poważnie zastanawia się nad naturą, celem i uzasadnieniem swojej pracy ${ }^{10}$. W niniejszym artykule chciałbym zakwestionować powyższe twierdzenia i pokazać, że kiedy edukacja jest właściwie rozumiana jako przedsięwzięcie ludzkie oraz odpowiednio przeprowadzana, to wówczas można ją postrzegać jako szczególny przypadek działalności praktycznej, posiadającej własną integralność. A zatem rzeczywistości, na jakie natrafimy w poniższych poszukiwaniach, mogą być rozumiane

lewski, Wydawnictwa Akademickie i Profesjonalne, Warszawa 2007].

${ }_{5}^{5}$ Por. A.C. MacIntyre, Three Rival Versions of Moral Inquiry, Duckworth, London1990. [Wydanie polskie: Trzy antagonistyczne wersje dociekań moralnych: etyka, genealogia i tradycja, tłum. M. Filipczuk, Wydawnictwa Akademickie i Profesjonalne, Warszawa 2009].

${ }^{6}$ Por. A.C. MacIntyre, Aquinas Critique of Education: Against his Own Age, Against Ours, [w:] Philosophers on Education, red. A.O. Rorty i in., Routledge, London 1998.

7 Por. A.C. MacIntyre, J. Dunne, Alasdair MacIntyre on Education: In Dialogue with Joseph Dunne, ,Journal of Philosophy of Education” 36(2002)1, 1-19.

${ }^{8}$ Por. tamże, s. 5.

9 Por. tamże, s. 9.

${ }^{10}$ Poza stwierdzeniem, że nauczanie nigdy nie jest niczym więcej jak tylko środkiem do celu, tezy MacIntyre'a mogą być zrozumiane jako zupełnie niekontrowersyjne, zwłaszcza wtedy, gdy zaliczy się do nauczycieli rodziców i inne osoby, od których dzieci uczą się (albo i nie) bardzo ważnych rzeczy, zanim jeszcze postawią swoją stopę w szkole, a także po jej zakończeniu. Na temat nauki nieformalnej MacIntyre przedstawia wiele ciekawych spostrzeżeń w pracy Dependent Rational Animals. 
zupełnie inaczej niż w myśleniu MacIntyre'a. Mój główny zamysł podziela wielu autorów niniejszego zbioru, z których większość zawiera uważne interpretacje i krytykę tekstów MacIntyre począwszy od pierwszego wydania Dziedzictwa Cnoty z 1981 roku. Jednakże proponuję obrać w moich poszukiwaniach nieco inną ścieżkę, na której nie zabraknie dzieł MacIntyre'a, ale na której zostaną uwydatnione inne postaci, a zwłaszcza często zapominany Sokrates z Aten.

\section{Wymknąć się myślącemu widmu}

Rozpoczynając nasze badania, chciałbym wpierw przyjrzeć się dwóm szeroko rozumianym charakterystykom nauczania, które pozostają aktualne w dzisiejszej dyskusji o wychowaniu: nauczanie jako „powołanie” i nauczanie jako ,zwykła praca”. Uznać, że nauczanie jest ,powołaniem" oznacza zająć pozycje skrajnie przeciwstawne wobec tych, które uznają że nauczanie jest „zwykłą pracą”, podobną do wielu innych zawodów, w których trzeba opanować pewien zestaw umiejętności i go zastosować. Bardziej wysublimowana wersja tej koncepcji głosi, że nauczanie jest zawodem ,specjalistycznym”, nawet „profesją”, ale unika przyznania mu statusu „powołania”. Z kolei koncepcja „powołania” ma długą historię w zachodniej edukacji, związaną głównie z dominacją Kościoła w tej dziedzinie. Koncepcja ta ma silne konotacje ze służbą pełnioną ze względu na cele bardziej wzniosłe aniżeli tylko wynagrodzenie pieniężne. Ponadto wiąże się ona z kościelnymi wymaganiami posłuszeństwa wobec władzy zwierzchniej. Pozycje przeciwne lub kwestionujące władzę kościelną (dzisiaj jest to władza demokratyczna), podkreślają koncepcję ,zwykłej pracy”. Widać to zwłaszcza w kampaniach związków nauczycielskich, gdzie pojawiają się subtelności i odmiany koncepcji „specjalistycznej”.

Obstawać przy koncepcji nauczania i uczenia się jako sposobu życia, jak zamierzam tutaj uczynić, oznacza celowo podejmować śmiałą próbę i mam nadzieję, że raczej roztropną niż pochopną. Krótko mówiąc, chodzi o odrzucenie zarówno koncepcji „,powołania”, jak i „zwykłej pracy” 
oraz całego spektrum pozycji pośrednich ${ }^{11}$. Chodzi o zakwestionowanie każdego poglądu, który utrzymuje, że nauczanie jest zasadniczo rodzajem pracy, specjalistycznej czy nie, o której rozstrzyga w szczegółach organ prowadzący, a którą wykonują podwładni według wskazań tego organu. Po drugie, chodzi o wyeksponowanie uczenia się: o przyznanie odpowiedniej rangi doświadczeniu i odpowiedzialności ludzkiego uczenia się w procesie nauczania. Powyższe uwagi sugerują, że uczynić z nauczania sposób życia oznacza profesjonalnie zaangażować się w taką formę działania, która ma własną autonomię i zadania, oraz rozumieć, że te dwie cechy konstytuują integralność tego sposobu ży$\mathrm{cia}^{12}$. W tej koncepcji istotne jest to, że właściwe naświetlenie, uznanie, ochrona, promocja tej integralności jest sprawą kluczową. Uznanie nauczania za specyficzny sposób życia jest ważniejsze niż np. rozróżnienie między nauczycielami poszczególnych przedmiotów, rozróżnienie między dziećmi a dorosłymi itp.

Powyższa koncepcja nie zapomina ani nie umniejsza historycznego i kulturowego kontekstu, w którym nauczanie i uczenie się mają nieuchronnie miejsce. Nie zapomina też o potężnych interesach, które zanegowały w historii ową integralność nauczania i uczenia się. Za-

${ }^{11}$ Mimo że potoczne używanie terminu ,profesja nauczycielska” nie stanowi problemu, mówienie o nauczaniu jako o „profesji” jest często nieuzasadnioną próbą zbudowania czegoś na tym pośrednim polu. Idąc popularną drogą porównywania nauczania do medycyny lub prawa jako „profesji”, próby takie natrafiają na różnice (np. natura relacji profesjonalista - klient, warunki i zasady zatrudnienia, zdolność inkasowania opłat), które sprawiają, że porównanie to jest bardziej obciążające niż pomocne, a w każdym razie umniejsza rozumienie tego, co jest najbardziej wyróżniające i pozytywne w nauczaniu jako działalności praktycznej.

${ }_{12}$ Formułując powyższe postulaty, jestem świadomy faktu, że potrzeba kilku stron, aby w pełni wyjaśnić powiązania, które leżą u podstaw mojej charakterystyki. Zamiast tych brakujących stron chcę tylko powiedzieć, że wiele zawdzięczam myśli Hannah Arendt o znaczeniu dzialania pośród „znikomości ludzkich spraw” oraz rozważaniom Paula Ricoeura o działaniu jako „dyscyplinie autonomicznej”, albo dokładniej, o „specyfice związku między działaniem a jego podmiotem". Por. H. Arendt, The Human Condition, University of Chicago Press, Chicago 1958, rozdz. 5 [wydanie polskie: Kondycja ludzka, thum. A. Łagodzka, Fundacja „Aletheia”, Warszawa 2000] i P. Ricoeur, Oneself as Another, thum. K. Blamey, University of Chicago Press, Chicago1992, s. 113 i nast. [wydanie polskie: $O$ sobie samym jako innym, tłum. G. Chełstowski, Wydawnictwo Naukowe PWN, Warszawa 2003]. 
mierzam wręcz podkreślić, że trwała odpowiedzialność, która charakteryzuje koncepcję nauczania jako sposobu życia, może czasem wchodzić w konflikt z instytucjami władzy i ośrodkami wpływu. Profesjonalne zaangażowanie, o którym mowa w poprzednim akapicie, jest bowiem podwójnym zaangażowaniem: w nauczanie i uczenie się jako ludzkie działanie, a nie wyłącznie w zestaw umiejętności, które trzeba opanować, przekazać, podzielić się nimi. Chodzi nie tylko o sprawność działania i komunikacji, ale o coś jakościowo innego; o poświęcenie się nauczaniu i uczeniu się rozumianemu jako specyficzny sposób bycia człowiekiem w świecie o bezprecedensowym pluralizmie stylów życia, wartości i zawodów.

W tym, co zostało powyżej nakreślone, napomknęliśmy już, jak mogłoby wyglądać pełniejsze opracowanie nauczania i uczenia się jako sposobu życia. To, o czym zaledwie wspomnieliśmy dotąd, wymaga teraz rozwinięcia, biorąc oczywiście pod uwagę raczej wprowadzający niż wyczerpujący charakter niniejszego artykułu.

\section{Przykład Sokratesa}

Najlepszego być może przykładu nauczania jako sposobu życia w historii cywilizacji zachodniej dostarcza Sokrates z Aten ${ }^{13}$. Mam zamiar odnosić się do historycznego Sokratesa i odróżnić go od wymyślnej figury „Sokratesa”, służącej jako nośnik poglądów Platona w późniejszych jego pismach. Historyczny Sokrates, o ile wiemy, nie pozostawił po sobie żadnych pism. Mamy jednak intrygujące „okna” na jego życie i pracę we wczesnych dialogach Platona i w pismach kilku innych

${ }^{13}$ Może ktoś postawić zarzut, że to wyróżnienie należy się Jezusowi Chrystusowi. Chociaż uważne odczytanie nowotestamentowych Ewangelii dostarcza argumentów za znaczącymi sukcesami Chrystusa jako nauczyciela, jednak wyłania z nich obraz nieciągły i niekompletny. Portret Sokratesa we wczesnych dialogach Platońskich, choć także daleki od ideału, daje więcej cech charakterystycznych niż u Chrystusa-nauczyciela w Ewangeliach. Posiada także wiele podobieństw do ewangelicznych opisów Chrystusa jako nauczyciela - między innymi tajemnicza sugestywność kryjąca się u podstaw działania obu. 
współczesnych autorów ${ }^{14}$. Lecz jakie znaczenie miałaby mieć tak dawna postać - Sokrates żył prawdopodobnie w latach 469-399 przed Chrystusem - dla nauczania w XXI wieku? Samo to pytanie brzmi dość ciekawie, zwłaszcza wobec obecnej międzynarodowej mobilizacji energii w okiełznywaniu technologii komunikacyjnych dla nowych celów edukacji i szkolenia.

Tam, gdzie nauczanie jest rozumiane głównie jako środek do zewnętrznego celu albo jako zestaw technik i umiejętności na usługach przedsięwzięć, których nauczyciel nie jest autorem, znaczenie Sokratesa będzie postrzegane jako nieistotne. Takie instrumentalne podejście do nauczania rzuca je na łaskę urzędników, niezależnie od tego jak mocno zakamuflowana jest ta rzeczywistość, niezależnie od tego jak wysoko opłacani są ci urzędnicy oraz niezależnie od tego, czy uczą w przedszkolu czy na uniwersytecie ${ }^{15}$. Nauczyciele są w tej koncepcji podwładnymi, w przeciwieństwie do nieprzymuszonych uczestników innych zawodów, posiadających własną autonomię i zadania. Tylko na takim instrumentalnym poglądzie może się opierać twierdzenie MacIntyre'a, że „nauczanie nie jest nigdy niczym więcej niż środkiem”. Tam zaś, gdzie praca człowieka polega na rutynowym i wydajnym wykonywaniu czynności narzuconych z góry, nie ma sensu mówić o źródłach inspiracji dla takiej pracy albo o jej wypełnianiu jako o sposobie życia. Właściwie nie ma sensu mówić wtedy o wychowaniu jako działaniu ludzkim,

${ }^{14}$ Warto, abym uzasadnił użycie tu i w innych miejscach liczby mnogiej „my”. Zdaję sobie sprawę, że takie użycie słów może być wykluczające albo nawet protekcjonalne - na przykład kiedy „my” jest pozornie uniwersalne, ale milcząco odnosi się do określonej grupy np. „europejscy intelektualiści”, „Zachodni liberałowie”. Dla wyjaśnienia więc: w niniejszym artykule użycie pierwszej osoby liczby mnogiej obejmuje wszystkie osoby na tyle zainteresowane wychowaniem, że myślą poważnie o sprawach nauczania i uczenia się, i są gotowe zrewidować swoje wcześniejsze założenia. Tezy artykułu są niewątpliwie zachodnie, choć szukają rozwiązań w zachodnich i niezachodnich nurtach intelektualnych.

${ }^{15}$ Pogląd jakoby nauczyciele byli tylko urzędnikami, zdaje się być traktowany jako uznany fakt przez Jean-Françoisa Lyotarda w jego wpływowej pracy The Postmodern Condition (tłum. G. Bennington, B. Masumi, Manchester University Press, Manchester 1984 [wydanie polskie: Kondycja ponowoczesna, tłum. M. Kowalska, J. Migasiński, Fundacja Aletheia, Warszawa 1997]). 
czyli o formie celowego działania, wewnętrznie uzasadnionego, które ma nie tylko trwać, ale rozwijać się.

$\mathrm{Z}$ drugiej strony, jeśli chcemy mówić o nauczaniu jako o zajęciu autonomicznym, z własnymi zadaniami, wówczas postać Sokratesa z Aten staje się pierwszoplanowa - nie dlatego, jakoby miał odpowiedzi na dzisiejsze pytania, ale jako swoista inspiracja. Chodzi o zakwestionowanie słuszności rozróżnienia na środki i cele, gdy mówimy o nauczaniu. Chodzi o radykalny pogląd, że nauczanie jest sposobem życia. Ktoś mógłby pokusić się o obwołanie Sokratesa „świętym patronem” nauczania jako sposobu życia, a przez to odróżnić ten sposób życia od koncepcji nauczania, które jest tylko zestawem umiejętności i technik używanych do zewnętrznych celów. Ale jakkolwiek cenne mogłoby być to posunięcie, zmierza ono znów do koncepcji nauczania jako ,powołania” i czyni z Sokratesa obiekt czci. A ponieważ ani świętość za życia, ani kanonizacja po śmierci nie były jego udziałem, pokusę tę możemy spokojnie odrzucić. To ułatwi nam zajęcie się ludzkim Sokratesem i jego myślą.

Pewne interesujące obserwacje wychodzą na światło dzienne, kiedy postać Sokratesa jako nauczyciela nie jest dłużej przykryta jego ,platońską" maską, często obecną w zachodniej filozofii, oraz kiedy dostęp do jego pracy nie jest przyćmiony pełnym szacunku przyjęciem ,metody sokratejskiej". Prawdopodobnie najciekawszą z tych obserwacji jest ta, że za całą pozorną nierozstrzygalnością dialogu sokratejskiego stoi specyficzne przekonanie samego Sokratesa. Wobec tego trzeba uznać, że cokolwiek nazwiemy „metodą sokratejską”, pozostanie to tylko pustym pojęciem bez zrozumienia tegoż przekonania. Kiedy jednak ktoś pojmie, czym jest to przekonanie, może zaobserwować jak ono działa w spotkaniach wychowawczych we wczesnych dialogach takich, jak Gorgiasz, Protagoras, Eutyfron czy pierwsza księga Państwa. W pracach tych Sokrates jest pokazany najprawdopodobniej jako prawdziwy Sokrates, spotykający się w domach i miejscach publicznych starożytnych Aten ${ }^{16}$. Znajomość tego przekonania umożliwia też rozpoznanie

${ }^{16}$ Różnica między historycznym Sokratesem, przedstawionym we wczesnych pismach Platona, a tym służącym jako figura literacka w późniejszych pismach, stanowi temat powracającej debaty i badań. Przykładowo dwa dzieła ze środkowego okresu 
postępu edukacyjnego, którego może ono dokonać mimo pozornego braku rozstrzygnięcia tych spotkań. W rzeczywistości - jak zobaczymy dalej - właśnie w tej nierozstrzygalności mogą być zawarte szczególnie obiecujące szanse.

Wczesne pisma Platona nie formułuja jednak jasno owego ciekawego przekonania Sokratesa i w rezultacie np. Gorgiasz czy Protagoras pozostawiają wrażenie, że kończą się tam, gdzie się zaczęły. Co bardziej irytujące, mogą skłaniać do wniosku, że Sokrates dla zabawy kluczy z rozmówcami w labiryncie poglądów, aby ich wprowadzić w zakłopotanie. Oczywiście taka irytacja przyczyniła się do postawienia Sokratesa przed sądem z podwójnym oskarżeniem: o bezbożność i demoralizację młodzieży ateńskiej. W dramatycznej mowie przed sądem, przytoczonej we wczesnym, krótkim dziele Platona - Obrona Sokratesa, ujawnione zostają przekonania, które kształtowały życie Sokratesa, zwłaszcza jego pracę wychowawcy. Sokrates dobrze rozumiał, że wypowiedź wyroczni delfickiej, jakoby był on „najmądrzejszym z ludzi” wywołała zazdrość u sofistów, których pozycja jako najbardziej prestiżowych nauczycieli została publicznie podważona. Tak więc Sokrates thumaczy ławie przysięgłych - złożonej z 501 obywateli - znaczenie wyroczni, które jest różne od tego, co rozumieją sofiści i inni obywatele: „W istocie podobno tylko Bóg jest mądry i Apollo w swej odpowiedzi daje do zrozumienia, że rozum ludzki nic nie znaczy albo tylko niewiele. Zdaje się, że dlatego moje imię wymienił, aby dać jako przykład, że ten jest najmądrzejszy, kto jak Sokrates poznał, że rozum jego niczym jest w powszechnej mądrości (tłum. F.A. Kozłowski)"17.

twórczości Platona, Menon i Uczta, kreślą intrygujący wizerunek Sokratesa jako wychowawcy, ale także jako wyraziciela głównych tez platońskiej metafizyki, co do których watpliwe jest, aby wypowiedział je prawdziwy Sokrates z Aten. Z tego powodu wyłączyłem te dzieła z jasno oddzielonej grupy zawierającej Protagorasa, Gorgiasza, Eutyfrona, Obrone Sokratesa i pierwszą księgę Państwa. Najciekawsze, nowe studium tego tematu, na jakie natrafiłem to Socrates: Ironist and Moral Philosopher autorstwa Gregory Vlastosa (Cambridge University Press, Cambridge 1991). Książka ta wyjaśnia różnicę w bardzo przystępny sposób i wzbogaca temat o wszechstronne studium dzieł Platona.

${ }^{17}$ Por. Plato, Apology (XXIII), [w:] The Dialogues of Plato in two volumes, thum. B. Jowett, Random House, New York 1937. 
Na pierwszy rzut oka może się wydawać, że słowa te pogrążają w beznadziei każde ludzkie nauczanie i uczenie się, a nie tylko naukę uprawianą przez sofistów. Dla Sokratesa jednak było wprost przeciwnie. Podjął się on - jak wyjaśnia ławie przysięgłych - udowodnienia nieprawdziwości wyroczni, a jego wysiłki doprowadziły go do zaangażowania w debatę z najwyżej cenionymi autorytetami Aten. W pierwszej chwili Sokrates był zaskoczony odkryciem, że mądrość wielu wiodących ludzi kultury w Atenach częściej okazywała się fałszywa niż prawdziwa. W miarę kolejnych rozmów, Sokrates odkrył prawdziwe znaczenie uczenia się, ponieważ stało się ono specyficznym sposobem życia. Wśród najważniejszych wniosków, jakie odkrył, był ten, że ograniczenie, stronniczość, chwiejny charakter, omylność są prawdopodobnie nieuniknionymi cechami wszystkich ludzkich dążeń do rozumienia i wiedzy.

Odkrycie to rzuca nowe światło na spotkania z młodymi Ateńczykami oraz ze starszyzną. W tych spotkaniach pytania Sokratesa pokazują ścieżki myślenia, które przeszedł wcześniej sam, lecz nie znalazł zadowalających odpowiedzi. Chętnie więc podążał nimi ponownie w towarzystwie innych. Poprzez takie wycieczki mogły się pojawić nowe wnioski, zdemaskować poprzednie zaułki, a skromny postęp w kierunku prawdy mógł się realizować.

Odniesienie do prawdy jest tu kluczowe, lecz nie chodzi o prawdę w sensie celu, do którego dochodzi się nieodwołalnie, z absolutną pewnością. W przeciwieństwie do platońskiego Sokratesa z późniejszych pism, dla Sokratesa z Aten prawda pozostaje tym, do czego ludzkie wysiłki zdążają, są stale w drodze. Postęp na drodze do prawdy to świadomość przejściowego, zawodnego charakteru tego wszystkiego, czego dostarczyło nawet najlepsze badanie, to znaczy tych efektów poszukiwań, które dają się obronić w ogniu krytyki. Podobnie postęp na drodze do prawdy oznacza dostrzeżenie przez refleksję nad owocami odkryć, że ostateczna prawda jest prawdopodobnie poza zasięgiem ludzkości i miarami, które ona posiada ${ }^{18}$. Stąd właśnie wynika konkluzja Sokra-

\footnotetext{
${ }^{18}$ Odniesienie do „prawdy ostatecznej” nie oznacza tutaj oczywiście ostatecznej prawdy o zdarzeniach, $\mathrm{z}$ jakimi mamy do czynienia w badaniach empirycznych doty-
} 
tesa, że „ostateczna prawda” albo „prawdziwa mądrość” jest raczej boska niż ludzka. To zaś oznacza, że im mądrzejsza jest ludzkość poprzez swoje wspólne wysiłki, tym bardziej docenia oraz odważniej krytykuje swoje dziedzictwo naukowe. A jednak, z tych samych względów, może się stawać coraz pokorniejsza wobec aspiracji ludzkiej wiedzy.

Na przykładzie Sokratesa z Aten możemy zobaczyć pewną szczególną koncepcję problemu nauczania i uczenia się. Ściślej rzecz ujmując, zaczynamy rozumieć tę koncepcję jako trwałe usposobienie wychowawcze, silnie kontrastujące z usposobieniem stawiającym bardziej na przymus, które dominowało przez większość historii zachodniej edukacji. Pamiętając o rozróżnieniu, dokonanym przez Pierre'a Hadota między filozofią jako profesjonalnym przedsięwzięciem teoretycznym a filozofią jako sposobem życia ${ }^{19}$, takie usposobienie refleksyjno-praktyczne można opisać jako odrębny rodzaj filozofii. Jest to rodzaj filozofii, który można nazwać właściwą filozofią wychowania albo przynajmniej wyraźnie rozpoznawalną formą filozofii wychowania. Taka filozofia jest obca metafizyce - rozumianej w sensie długiego i urozmaiconego poszukiwania miarodajnego i pełnego wyjaśnienia całej rzeczywistości w późniejszych pismach Platona. Jest też obca racjonalistycznej epistemologii i jej różnym „naukowym” pochodnym - rozumianym jako poszukiwanie w ostatnich wiekach stabilnych i pewnych podstaw wszelkiej wiedzy. Jednak pełne znaczenie wychowawcze tego sokratejskiego rodzaju filozofii wyjaśnia się wówczas, gdy rozumiemy, że tezy dotyczące prawdy i omylności, które padły wyżej, odnoszą się nie tylko do prawdy jako twierdzeń i założeń. Odnoszą się bowiem do prawdy jako wskazówki, jak należy przeżyć wlasne życie. Tu ujawnia się zarówno nieuchwytny, jak i kuszący charakter prawdy, która pozostaje dla ludzi źródłem ciągłego, niekończącego się poszukiwania.

Powrócimy później do analizy wniosków z tej dyskusji dla nauczania i uczenia się w naszych czasach. Warto tutaj jeszcze przyjrzeć się bardzo

czących pytań takich, jak "Kto chciał zabić J.F. Kennedy'ego?" czy "Ile dublińskich pubów zostało wymienionych w powieści Joyce'a Ulysses?".

${ }^{19}$ Por. P. Hadot, Philosophy as a Way of Life, thum. M. Chase, Blackwell, Oxford 1995. 
odmiennej perspektywie nauczania i uczenia się, która dominuje w cywilizacji Zachodu. Jest to mianowicie pogląd, który odmawia wychowaniu jako działalności praktycznej wiele z tego, o czym mówi MacIntyre, ale z innych powodów. Nie czerpie on z zachodniego ani w ogóle z żadnego dziedzictwa kulturowego. Jednak zwolennicy tego stanowiska chętnie uznają, być może z oportunistycznych powodów, jego pochodzenie od tego dziedzictwa. Jest to stanowisko niemające powiązania $\mathrm{z}$ omawianą wyżej tradycją sokratejską, a także odcinające się od tradycji metafizycznych, które z czasem przyćmily i zastapiły tradycję sokratejską w zachodnim chrześcijaństwie oraz w późniejszej historii zachodniej edukacji aż do czasów nowożytnych ${ }^{20}$.

\section{Uczenie się jako strategia, wydajność jako sposób życia}

W tak zwanym „społeczeństwie uczącym się” (learning society) czy „społeczeństwie informacyjnym” (information society) uczenie się osiaga bezprecedensowe znaczenie. Jest to wszakże często znaczenie strategiczne, związane z celami komercyjnymi albo celami narodowej polityki ekonomicznej i społecznej. W tej perspektywie makro, dominującej wśród klasy rządzącej w dobie globalizacji, uczący się są postrzegani jako ważne zasoby ludzkie (human resources) na międzynarodowym rynku konkurencji. Cele nauczania, jego treść i obserwowana jakość, są skrupulatnie przeliczane. Samo nauczanie coraz częściej jest postrzegane jako zestaw umiejętności: co ciekawe, umiejętności te mogą być skutecznie wyszczególnione i przeliczone przy pomocy elektronicznych operacji w systemie e-learningu. Nauczanie jako działanie ludzkie w tej perspektywie ustępuje, zostaje odsunięte na bok, poza granice nauki i jej postępu.

Z punktu widzenia powyższych argumentów tym, co najbardziej uderza w oficjalnej literaturze na temat „społeczeństwa uczącego się” jest

\footnotetext{
${ }^{20}$ Przechodząc do naszych czasów, pomijam oczywiście dwa bardziej interesujące okresy w historii zachodniej edukacji, a mianowicie średniowiecze i oświecenie. Swego czasu podjąłem próbę zbadania tychże okresów w mojej książce The Custody and Courtship of Experience: Western Education In Philosophical Perspective (Columba Press, Dublin 1995), w rozdziałach 2, 3 i 4.
} 
brak zainteresowania kulturą. Wyraźnie widać to w wydanej przez Komisję Europejską w 1996 roku tzw. Białej Księdze Nauczanie i Uczenie się: na drodze do uczqcego się społeczeństwa. Dokument ten stanowi kamień milowy, który celowo zaciera różnicę między kształceniem a doskonaleniem zawodowym, a jednocześnie odzwierciedla i kształtuje charakter polityki edukacyjnej w większości krajów Unii Europejskiej w ostatnich latach ${ }^{21}$. Dał też początek nowemu rodzajowi w oficjalnej literaturze dotyczącej wychowania ${ }^{22}$ i doprowadził do kolejnych fal inicjatyw, popartych finansowo, które są zaprojektowane tak, aby nadać nowy kierunek narodowym politykom edukacyjnym w rozszerzającej się Unii Europejskiej. Jak należy postrzegać i kultywować uczenie się w „społeczeństwie uczącym się” wynika z pięciu głównych celów określonych w Białej Księdze. Są to:

1. Promocja nowej wiedzy potrzebnej do przyspieszenia rozwoju technologicznego.

2. Zbliżenie szkoły i przedsiębiorstwa.

3. Walka z wykluczeniem społecznym.

4. Osiagnięcie biegłości w trzech językach Unii Europejskiej.

5. Traktowanie na równi inwestycji materialnych i edukacyjnych.

${ }^{21} \mathrm{Na}$ temat znaczenia kultury w wychowaniu wspomniana powyżej Biała Księga stwierdza, co następuje: „Istotnym celem kształcenia i doskonalenia był zawsze osobisty rozwój i integracja Europejczyków w ramach społeczeństwa poprzez wyznawanie wspólnych wartości, przekaz dziedzictwa kulturowego i nauczanie samodzielności (tłumaczenie własne - M.M.)" (European Commission, Teaching and Learning: Towards the Learning Society - A White Paper on Education and Training, Brussels 1996, s. 18. Po pierwsze, fragment ten ignoruje rozróżnienie między kształceniem a doskonaleniem zawodowym, które było ważną częścią dyskusji o wychowaniu w większości krajów Europy od czasów Platona i Arystotelesa. Po drugie, zaciemnia on zróżnicowanie tego, co trwałe w dziedzictwach europejskich cywilizacji, jednocześnie próbując wcisnąc do eksploatacji „europejskie dziedzictwo kulturowe”, aby przyspieszyć nadejście nowej ortodoksji edukacyjnej w krajach członkowskich Unii Europejskiej. Biała Księga nie uznaje nawet $\mathrm{w}$ minimalnym stopniu takich spraw, jak tożsamość, uznanie czyjejś wartości oraz odmienność - spraw, które są nieodzowne dla europejskiego „bogactwa i różnorodności kulturowej” (tamże, s. 17), które ten sam dokument przywołuje. Fakt ten wskazuje na nieznajomość bogatej literatury na te tematy.

${ }^{22}$ Wiele z tej literatury można znaleźć na funkcjonującej od roku 1995 stronie Dyrekcji ds. Wychowania i Kultury (Directorate of Education and Culture) Komisji Europejskiej. 
Pierwszy, drugi i ostatni z tych celów jest oczywiście celem polityki ekonomicznej. Trzeci - walka z wykluczeniem społecznym - jest celem polityki społecznej. Może też być zasadą praktyki wychowawczej. Lecz jako taki musiałby objąć sprawy sprawiedliwości i korzyści edukacyjnych z nauczania i uczenia się, nie tylko sprawy dostępu do nauki lub jego braku. Czwarty cel - biegłość komunikacji w trzech językach Unii Europejskiej - może być celem edukacyjnym, ale zależy to od powodów, dla których owa biegłość jest promowana - ze względu na korzyści kulturowe uczącego się czy dla ułatwienia wymiany handlowej między krajami w ramach wspólnego rynku ${ }^{23}$. Za tym, że mamy do czynienia z drugą opcją przemawia myślenie inspirowane rynkiem oraz indywidualistyczne przesłanie Białej Księgi. Indywidualizm jest widoczny we wstępie, w tej i podobnych deklaracjach: „Poziom umiejętności osiągnięty przez każdego musi zostać zamieniony $\mathrm{w}$ instrumenty pomiaru indywidualnej wydajności w sposób gwarantujący możliwie równe prawa pracownikom” ${ }^{24}$ oraz „Każdy musi być w stanie wykorzystać możliwości doskonalenia dla społeczeństwa i wlasnego spelnienia, bez względu na swoje pochodzenie społeczne i poziom wykształcenia" 25 .

Pomimo odniesień do praw, równości i włączania w społeczeństwo, tu i w innych miejscach dokumentu występuje poważne zaniedbanie, a dotyczy ono powiązania między kształceniem publicznym a pytaniem o to, jak najlepiej można się spełniać jako obywatel. Z nielicznymi wyjątkami - a jest nim wydany w 1996 roku przez UNESCO raport Edukacja, jest w niej ukryty skarb - w całej oficjalnej literaturze ,uczącego się społeczeństwa" brakuje intelektualnej i duchowej troski o to, co na dobre i na złe było obecne przez większość historii zachodniej eduka$\mathrm{cji}^{26}$. Jakkolwiek trafna byłaby ta krytyka, przyjęcie jej jako adekwat-

\footnotetext{
${ }^{23}$ Nie mówię, że ten drugi cel - handlowy - jest nieistotny i nie powinien odgrywać żadnej roli w edukacji. Owszem odgrywa, ale nie tyle jako cel, lecz jako wtórna konsekwencja.

${ }^{24}$ European Commission, Teaching and Learning..., dz. cyt., s. 17.

25 Tamże.

${ }^{26} \mathrm{~W}$ przeciwieństwie do Białej Księgi Komisji Europejskiej, raport ekspertów Międzynarodowej Komisji ds. Edukacji dla XXI wieku, działającej pod przewodnictwem Jacques'a Delorsa, odznacza się rzeczywistym zatroskaniem o wychowanie obywatel-
} 
nej analizy nowej europejskiej polityki edukacyjnej oznacza pozostawienie poza nawiasem czegoś jeszcze ważniejszego. Tym ważniejszym jest spostrzeżenie, że w oficjalnej dyskusji na temat „uczącego się społeczeństwa" padła już odpowiedź na pytanie o relację między uczeniem się a tym, jak człowiek powinien żyć. Odpowiedź ta jest o tyle skuteczniejsza, że niewyartykułowana. Słusznie można powiedzieć, że ten nowy międzynarodowy dyskurs odsuwa w cień tradycyjne kulturowe i duchowe cele edukacji. Lecz to jeszcze za mało, aby dotknąć sedna sprawy. Otóż owe cele zostały naprawdę zastąpione, a w ich miejsce wprowadzono nowe credo, jeśli wolno użyć słownictwa religijnego. Nowe credo promuje nową doktrynę uniformizacji i uważa edukację, prowadzoną przy pomocy publicznych pieniędzy, za jedną z jej głównych nośników. Na pierwszy rzut oka twierdzenie to może wydać się dziwne w dobie rosnącego pluralizmu i sekularyzacji, więc domaga się pewnego wyjaśnienia.

Autorzy tacy, jak Jean-Françoisa Lyotard, w swoich analizach „kondycji ponowoczesnej” krajów uprzemysłowionych poświęcają sporo uwagi kryterium wydajności, czyli „optymalizacji globalnej relacji tego, co na wejściu z tym, co na wyjściu"27. Owo kryterium, jak argumentuje Lyotard i inni, w dużej mierze zastapiło tradycyjne wymagania uzasadnienia czy legitymizacji zarówno w sektorze publicznym, jak i prywatnym. Jako podstawa celowego działania, stopniowo zastapiło ruchy na wielką skalę (meta-narracje) o charakterze politycznym, filozoficznym czy religijnym, które we wcześniejszych wiekach starały się podbić serca i umysły tłumów. Według Lyotarda, edukacja padła ofiarą „programowania całości społecznej jako zwykłe narzędzie optymalizacji wydajności”28.

skie. Mimo że przewodniczący komisji był swego czasu prezydentem Komisji Europejskiej, jego raport został przyćmiony przez Białą Księgę i wiele następnych jej dokumentów, dotyczących kształtowania polityki edukacyjnej w krajach Unii Europejskiej.

27 J.F. Lyotard, The Postmodern Condition: A Report on Knowledge, trans. G. Bennington, B. Masumi, Manchester University Press, Manchester 1984, s. 46 [cyt. za: Kondycja ponowoczesna. Raport o stanie wiedzy, tłum. M. Kowalska, J. Migasiński, Fundacja „Aletheia”, Warszawa 1997, s. 49].

${ }_{28}$ Tamże, s. 47 [cyt. za: Kondycja ponowoczesna ..., dz. cyt., s. 51-52]. 
Zobaczymy później, czy rzeczywiście Lyotard ma w pełni rację w tej sprawie, jednak trudno powątpiewać w to, że kryterium wydajności jako świeckie i najemne credo, stanowi początek nowej uniformizacji. Przedefiniowuje ono kwestie jakości w kwestie zaksięgowanej ilości. Przenika sfery debaty publicznej - w gospodarce, w polityce i nie mniej w edukacji - w postaci coraz bardziej wysublimowanych „,wskaźników skuteczności” i operacyjnie definiowanych „kompetencji”, z zaniedbaniem bardziej adekwatnych i wnikliwych ocen trwałych osiągnięć. Rozszerza swoje panowanie przez zniewalającą moc zaprzęgania energii moralnych w jarzmo pragmatycznej efektywności, zamiast wezwać te energie do osiagania jakościowo wyższych celów ${ }^{29}$. Zmierza do pozbawienia odpowiedzialności jej zdrowych intencji i do ponownego zdefiniowania jej w kluczu legalizmu. Na różne sposoby kolonizuje się kulturę pracy i w ogóle kulturę ludzkich wysiłków, promując taki etos, w którym wartości związane $\mathrm{z}$ władzą i pieniędzmi gwarantują uprzywilejowane pozycje do oceniania tych, którzy podlegają władzy. W tej analizie widać, jak królestwo wydajności zdobywa - choć robi to tylnymi drzwiami - niektóre ważne kwestie dotyczące sposobu życia jednostek, a nie tylko wykonywania przez nie zawodów. W ten sposób zdobywa wpływową pozycję porównywalną z tą, którą niegdyś posiadały instytucje religijne.

W ramach takiego etosu łatwo zrozumieć, dlaczego wielu nauczycieli chce postrzegać swoje zajęcie jako „zwykłą pracę”, czyli jako zestaw umiejętności i technik, którego zastosowanie nie wymaga silnego zaangażowania serca i umysłu. Pocieszając się klimatem zdrowego rozsądku, taka racjonalizacja unika bardziej niepokojącego odkrycia, którego dostarcza bardziej spostrzegawcza samoświadomość. Właściwie każde codzienne zajęcie może zilustrować poniższą myśl, ale najbardziej trafny wydaje się przykład nauczania. Jeżeli bowiem uzna się, że nauczanie jest sposobem życia, ale na warunkach dyktatury wydajności, to trzeba również się zgodzić, że jest to sposób życia gorszy, a dlatego gorszy, że

${ }^{29}$ W trzecim rozdziale książki Whose Justice? Which Rationality? da się zauważyć pewne paralele między moim rozumowaniem a argumentacją Alasdaira MacIntyre'a odnośnie do dobra związanego z doskonałością i dobra efektywności. 
służebny, już nie wobec władz kościelnych, lecz ich świeckich następców o mentalności menadżerów. Krótko mówiąc, jeśli ktoś nie zacznie od solidnej i wyraźnej koncepcji nauczania jako sposobu życia z własną autonomią wypływającą $\mathrm{z}$ wewnętrznych motywacji, to właściwie już się zgodził na zajęcie stanowiska mniej uprzywilejowanego, a wręcz przegranego. Przystał na pogląd, że to, do czego dąży nauczanie i uczenie się, jest sprawą, w której dyskusje między nauczycielami i dorobek tradycji nauczycielskich nie mają pierwszorzędnego znaczenia. Pozwolił tym samym, żeby wiodącą rolę odgrywały oficjalne organy, których polecenia należy wykonywać, a nie poddawać je w wątpliwość. Chcąc nie chcąc, porzucił przekonanie, że nauczanie i uczenie się jako sposób życia może stanowić jeden z najbardziej wartościowych sposobów bycia człowiekiem.

Powyższe obserwacje podkreślają konieczność ustalenia, jak w dzisiejszych czasach powinna wyglądać solidna, możliwa do obrony i obiecująca, koncepcja nauczania jako sposobu życia oraz jak w praktyce można korzystać z jej autonomii. Spróbujemy zarysować to w dwóch ostatnich częściach. Pierwsza będzie skoncentrowana na tym, czemu taka koncepcja nauczania musi stawić czoła, druga zaś będzie raczej konstruktywnym pytaniem o praktyczne wnioski.

\section{Poza władzą i wydajnością}

Z tego, co przedstawiliśmy do tej pory, widać wyraźnie, że nauczanie jako sposób życia czerpie swój specyficzny charakter z wewnętrznej relacji do uczenia się jako działania ludzkiego i z faktu, że stawia pytanie o to, jak należy przeżywać własne życie. Jeśli jednak uczenie się postrzegamy głównie jako narzędzie stopniowego podporządkowywania sobie ludzi i rzeczy - niezależnie od rodzaju tego podporządkowania: technologicznego, ekonomicznego, administracyjno-politycznego - wówczas nauczanie jest widziane jako środek do osiagnięcia tejże dominacji. W średniowiecznym chrześcijaństwie takie postrzeganie nauczania i uczenia się - jako narzędzia teologicznej dominacji - było częste, ale nie powszechne. Sprawiało, że możliwa była, rzekomo ze 
względów duchowych, głęboka kościelna kontrola edukacji. Owa, trwająca wieki, kontrola ugruntowała przekonanie, że nauczanie jako zajęcie czerpie swoje uzasadnienie nie tyle $\mathrm{z}$ wewnętrznych celów związanych z uczeniem się i poszukiwaniem prawdy, lecz od wyższej władzy, która zapewniła sobie możność narzucania własnych prawd i forsowania swojego zdania wszędzie, gdzie podejmuje się poważne studia.

Totalitarne reżimy byłego bloku wschodniego dostarczają dobrych przykładów na to, jak koncepcja nadzoru nad nauczaniem i uczeniem się uzyskała nowe i żywotne wcielenie. Jednak twierdzenie, że ze względu na rozdzielenie władzy państwowej i kościelnej w nowoczesnych demokracjach albo na zmierzch wschodniego komunizmu, niebezpieczeństwo nadzoru nad nauczaniem i uczeniem się jest sprawą przeszłości oznacza przeoczenie czegoś bardzo istotnego. Albowiem, podczas gdy instytucje religijne stawały się coraz bardziej głosem pokrzywdzonych i marginalizowanych $\mathrm{w}$ zachodnich społeczeństwach, władze świeckie przejmowały po nich puste miejsca i przekształcały je w świecki trybunał. Ministerstwa edukacji w zachodnich demokracjach obejmowały tradycyjny nadzór nad wychowaniem - w takiej czy innej formie - i przykrajały go do swoich celów ${ }^{30}$. Innymi słowy, z radosną lub wyrachowaną beztroską wobec nowoczesnej, demokratycznej myśli edukacyjnej - jak np. poglądów Johna Dewey'a - wzięły edukację publiczną głównie za jedno z narzędzi władzy politycznej.

Widzieliśmy już owoce tej beztroski i arogancji, gdy analizowaliśmy istotę wydajności tego nowego credo epoki post-religijnej, które redefiniuje kwestie jakości i celu jako kwestie ilości i skuteczności. Nie znaczy to jednak, że sprawy jakościowe w edukacji są zaniechane. Raczej chodzi o akcentowanie, że teraz ich znaczenie nie wypływa z wewnętrznych wartości wychowawczych, ale ze skuteczności w osiąganiu celów polityki społecznej czy ekonomicznej ustalanych przez rządy. Ta zmiana w myśli i praktyce wychowawczej prowadzi do zredukowania spuści-

${ }^{30}$ Należy zauważyć, że mój własny kraj (Irlandia), choć w toku reform edukacyjnych, przechodził przez trudności i kontrowersje, jest pewnym pozytywnym wyjątkiem od tego międzynarodowego schematu, o którym mówię. Por. Report on the National Education Convention, red. J. Coolahan, The Stationery Office, Dublin 1994. 
zny nauki do swego rodzaju surowca, który ma służyć napędzaniu wyższych stopni mierzalnej wydajności. Zmiana ta zniekształca też koncepcję sprawiedliwości w edukacji. Sprawiedliwość - włączając w to sprawy związane np. z nierównością $\mathrm{w}$ dostępie do edukacji - traci tu swoje właściwe znaczenie dla codziennej praktyki nauczania i uczenia się. Właśnie w kontekście codzienności sprawy potrzeb i praw są obecne w najbardziej pilny i praktyczny sposób. Przez takie zniekształcenie pojęcie sprawiedliwości zostaje przedefiniowane jako element funkcjonalny przedsięwzięcia makroekonomicznego, a przez to jego etyczne wyzwania zostają w bezpośrednim spotkaniu nauczycieli i uczniów odsunięte na bok, jeśli nie wręcz zaciemnione. Jeśli na przykład zapytamy, dlaczego „walka z wykluczeniem społecznym” zyskała status głównego celu edukacyjnego, trudno nie być zaskoczonym odpowiedzią, którą daje analiza Lyotarda o interakcji władzy i wydajności: „W ramach kryterium władzy, żądanie nie zyskuje większego uzasadnienia przez fakt, że jest oparte na cierpieniu spowodowanym niezaspokojoną potrzebą. Prawa nie wypływają z cierpienia, ale z faktu, że ulżenie cierpieniu usprawnia wydajność systemu. [...] W tym sensie system wydaje się lokomotywą ciągnącą za sobą ludzkość, dehumanizującą ją po to, aby na nowo ją uczłowieczyć na innym poziomie normatywnej pojemności. [...] Taka jest arogancja ośrodków decyzyjnych - i ich ślepota" ${ }^{\text {31 }}$.

Mimo emocjonującego odkrycia dokonanego w logice przez Lyotarda, pójście do końca drogą tej analizy doprowadziłoby do wniosku, że najbardziej zaawansowane technologicznie kraje świata stały się totalitarnymi technokracjami, że nie ma już miejsca na intelektualne czy praktyczne działanie, chyba że to działanie byłoby jakąś formą koncepcji wydajności i skuteczności - czyli środków przymusu. Oczywiście konkluzja taka jest bardzo ogólna, ale krótki przykład powinien rozjaśnić jej adekwatność dla nauczania i uczenia się. Jeśli ktoś miałby zastosować ten rodzaj analizy, np. do społeczeństw przednowoczesnych, wniosek byłby taki, że są one despotycznymi teokracjami, w których konstruktywne działanie inspirowane motywami innymi niż teokratyczne było-

${ }^{31}$ J.F. Lyotard, The Postmodern Condition..., dz. cyt., s. 62-63. 
by zawczasu wyeliminowane. I choć znajdzie się sporo dowodów historycznych na poparcie tej analizy, trzeba powiedzieć, że ignoruje ona wszelkie dowody przeciwne, które by ją podważały. Na przykład, jeśli analiza w pełni opisywałaby rzeczywistość, wiele przełomowych teorii w zachodniej nauce zostałoby skutecznie udaremnionych, jak np. prace i oddziaływanie myśli Erazma, Kopernika czy Galileusza.

Ogólny charakter niektórych wniosków Lyotarda nie powinien jednak rzucać cienia na to, że jego analizy dostarczają wnikliwych i otrzeźwiających obserwacji na temat ruchów i trendów, które w późnej nowoczesności stały się dominujące. Zwłaszcza jego odkrycia dotyczące wydajności pokazuja, jak zdradziecko można zastapić racjonalność, która obmyśla i przeprowadza duże publiczne przedsięwzięcia, oraz osłabić sens takich pojęć, jak jakość i sprawiedliwość. A skoro owe przekłamania wychodzą na światło dzienne z mroku międzynarodowych „demokratycznych" wypowiedzi, mogą zostać poddane krytyce i dzięki temu ich siła zaczyna słabnąć. Na przykład nauczyciele zobaczą, że kiedy odrzeć z populistycznej aury credo wydajności, okaże się ono niegodne ich zawodowego zaangażowania. Oczywiście pod warunkiem, że nie zadowolą się oni - z jakiś względów - rolą funkcjonariuszy czy urzędników tego credo. To samo twierdzenie, choć z pewnymi różnicami, odnosi się do zarządzania szkołami, do studentów i do rodziców dzieci w wieku szkolnym.

Ideolodzy „skuteczności” zaangażowania zawodowego zajmują zwykle stanowiska przywódcze w polityce, handlu czy administracji. Warto dodać, że w większości nie są to ludzie działający świadomie ze złej woli. Jako „cywilizowani” ludzie, postrzegają siebie jako adwokatów dobrych celów takich, jak „wyższe standardy”, „rokroczny wzrost”, „rosnąca konkurencyjność”; wszystkie te cele są dziś uważane za same przez się dobre i prowadzące do lepszego życia w wysoko uprzemysłowionym społeczeństwie. Podobna retoryka cechuje współczesny dyskurs na temat „najlepszej praktyki” w większości zawodów. O ile jednak podobne trendy stają się dominującym wzorem także w myśli i praktyce wychowawczej, o tyle tracą one z oczu to, co odróżnia nauczanie i uczenie się jako sposób życia, to znaczy zaciemniają fakt, że nauczanie, 
w najpełniejszym i najtrwalszym sensie tego słowa, jest zasadniczo poświęceniem się dla najbardziej wartościowego aspektu uczenia się jako sposobu bycia człowiekiem.

\section{Nauczanie i uczenie się jako aktywna relacja}

Po tych uwagach dochodzimy do miejsca, w którym charakter i znaczenie nauczania jako sposobu życia może zostać określone dokładniej. $\mathrm{Z}$ tego, co powiedzieliśmy do tej pory, jasne jest, że inspiracja sokratejska ma kapitalne znaczenie dla tego sposobu życia. Naturalnie nie chcemy nawoływać do powrotu do przeszłości ani do wcielenia Aten z IV wieku przed Chrystusem w historyczną i kulturową rzeczywistość XXI wieku. Chodzi nam raczej o to, żeby podejść z całą ostrością umysłu i otwartością serca do dziedzictwa nauki. Chodzi także o próbę rozeznania, co w tym dziedzictwie najbardziej zasługuje na wiarę i na trwały wysiłek praktyczny, gdy trzeba będzie zaangażować się szczerze w nauczanie jako działanie ludzkie czy ogólniej - w edukację jako przedsięwzięcie ludzkie. Takie spojrzenie na sprawę ujawnia inne istotne problemy. Przede wszystkim ten, że praca nauczyciela nigdy nie jest oderwana od jakiejś filozofii wychowania, wyraźnej lub domniemanej32. Taka filozofia jest ponadto nieustannie wzbogacana o szereg odziedziczonych wpływów, włączając w to współczesne, a nawet najnowsze. Za filozofię tę uznajemy także wydajność - czy to aktywnie przyjętą jako credo czy bezrefleksyjnie obecną w energicznym wypełnianiu czyjejś pracy, czy wreszcie gniewnie znoszoną jako codzienny ciężar. Przywołując naszą wcześniejszą dyskusję, filozofia wychowania - jako dyscyplina refleksyjno-praktyczna - może rozpoczać swoją owocną pracę od poddania refleksji tychże odziedziczonych „,filozofii”.

${ }^{32}$ Uznać w pełni ten punkt to zmierzyć się także z wielorakimi i wymagającymi konsekwencjami w sposób intelektualnie uczciwy oraz uznać (wbrew MacIntyre'owi w jego wywiadzie z Dunne), że filozofia wychowania jest wyodrębnioną sferą poszukiwań filozoficznych. Oznacza to również stawienie czoła wielu różnym wymaganiom stawianym przez zinstytucjonalizowane formy filozofii akademickiej. 
Sokratejskie rozumienie nauczania i uczenia się podkreśla punkt obecny w każdej filozofii wychowania: nie tylko „co” - czyli specyficzny zbiór treści, ale także „dlaczego" - czyli pewne poczucie sensu i słuszności, wreszcie ,jak" - czyli spektrum postaw, dyspozycji i praktyk, poprzez które osiagga się cele, mniej lub bardziej wiernie. Pogląd, że nauczanie jest sposobem życia, wymaga dookreślenia i uzasadnienia wszystkich tych pytań: „co”, ,dlaczego” i ,jak”. W związku z tym warto zauważyć, że wszystkie trzy pytania zbiegają się w sposób naturalny, kiedy nauczanie i uczenie się są rozumiane nie jako osobne czynności, ale jako relacja, w którą wchodzą nauczyciele i uczniowie, każdy z innej perspektywy kulturowej. I znów przykład Sokratesa okazuje się szczególnie ciekawy. Dostarcza nie tyle konkretnych wskazówek, co raczej płodnych idei dla zrozumienia „dlaczego" edukacyjnych celów, „co" substancji edukacyjnej (czyli głosów tradycji) oraz ,jak” nauczania i uczenia się (czyli zaangażowania czynnego w tę tradycję).

Sokrates prowadził swoją działalność wśród studentów na zasadzie wciąż ponawianego zaproszenia do współuczestnictwa w podjętych poszukiwaniach. Dla nauczyciela oznacza to stać się - przynajmniej w jakimś stopniu - praktycznym filozofem według powyższego wzoru. Tam, gdzie w grę wchodzi codzienna praktyka nauczania i uczenia się, należy uważnie nadstawiać uszu na wiele różnych głosów tradycji, aby umiejętnie wydobyć z nich to, co przemawia do ludzkiej wyobraźni i wrażliwości. Po drugie, oznacza to także dla nauczyciela rozwijać wrażliwość na zdolność uczniów do wyczuwania tych głosów. Po trzecie, chodzi o takie udoskonalanie zakresu zdolności komunikacyjnych, aby wydobyć od studentów odpowiedzi i kształcić ich w kierunku samokrytycznego i coraz bardziej sprawnego zaangażowania wobec tych głosów. Trzeba tu zauważyć, że każdy przedmiot, na przykład historia, muzyka czy matematyka, może zawierać głosy różnorodne, nawet przeciwstawne sobie. „Dobra”, których poszukuje nauczyciel, nie są więc oderwanymi „dobrami” matematyki czy historii, czy nauk przyrodniczych. Nauczanie jako sposób życia jest tworzone raczej przez kompleksową praktykę i podtrzymywanie w relacji uczenia się, w którym głosom historii, poezji, nauk przyrodniczych itp. pozwala się przema- 
wiać, i otrzymuje się krytyczną, lecz wspaniałomyślną odpowiedź od uczniów. Trudno sobie wyobrazić, czym miałyby być te „dobra” matematyki, historii czy nauk przyrodniczych, jeśli nie wewnętrzną korzyścią uczenia się, realizowaną dzięki takim czynnościom - rozwijaniem umysłu i serca.

Oczywiście dla Sokratesa nauczanie wymagało czasem krytycznego użycia takich narzędzi, jak ironia, droczenie się, szyderstwo, pochlebstwo i sporadycznie ośmieszenie. Studium wczesnych dialogów Platona (np. Gorgiasz, Protagoras, Eutyfron, pierwsza księga Państwa) pokazuje wszakże, że narzędzia te były wykorzystywane tylko wtedy, gdy arogancja, zarozumiałość czy drażliwość tego czy innego rozmówcy, stała na drodze wysiłków badawczych. Zdaje się, że Sokrates nie stosował tych forteli wobec otwartych na wiedzę uczniów.

Refleksja nad tymi punktami - a także kontrast $\mathrm{z}$ umiejętnościami i technikami sofistów - wyjaśnia ironiczny cel odmowy Sokratesa wobec nazwania siebie nauczycielem. Rzuca też światło na jego wyznanie przestawione w Gorgiaszu, że oddawał się „sztuce prawdziwej polityki”, która polegała na uprawianiu „działalności społecznej”. Podobna misja może zabezpieczyć filozofię wychowania przed przekształceniem się w ideologię albo technologię, albo teoretyczną czynność, której brakuje spójnego poglądu na własne, ważniejsze cele: mianowicie cele wyjaśniania i doskonalenia, zabezpieczania i promocji ,prawdziwej sztuki politycznej" nauczania i uczenia się.

Umieszczając postać Sokratesa z Aten w centrum niniejszego eseju, próbowałem przywołać te postawy, dyspozycje i działania, które konstytuują ową „sztukę polityczną”, sztukę, która nie może już bardziej różnić się od tej, którą uprawia się w konwencjonalnej polityce. Praktyczny charakter tych postaw i dyspozycji jest widoczny w ich przeplataniu się albo w sztuczności rozróżnień na postawy, dyspozycje i działania. $Z$ tego powodu ściślej powiedzielibyśmy o dyspozycji do działania. Trzeba odróżnić owe dyspozycje do działania, będące owocem praktycznego rodzaju myślenia filozoficznego, od religijnych koncepcji posłuszeństwa i jego różnych wymagań oraz od politycznych koncepcji lojalności wobec partii czy jej lidera. Ich specyficzny charakter - jak 
został naszkicowany poniżej - jest kluczowy dla określenia nauczania jako odrębnej praktyki albo ogólniej - jako odrębnego sposobu bycia człowiekiem. Oczywiście nie znaczy to, jakoby każda chwila życia nauczyciela była poświęcona tej praktyce. Trzeba jednak powiedzieć, że dyspozycje do działania, które charakteryzują nauczanie jako sposób życia, przybliżają nauczycielowi (w sposób niewymuszony) możliwości bogatego, twórczego życia społecznego i kulturalnego; możliwości, które w przeciwnym wypadku mogłyby leżeć poza czyjąś świadomością.

Dyspozycje do działania, o których mowa, są zbyt liczne, by je tutaj wyczerpująco zlustrować, lecz na pewno w każdym streszczeniu pojawiłyby się następujące: czujne docenienie faktu, że ,sam Bóg tylko jest mądry" i idąca za tym świadomość wewnętrznych ograniczeń najlepszych nawet ludzkich poszukiwań; uznanie zarówno skromności, jak i coraz to nowych perspektyw cechujących naukę jako przedsięwzięcie niedokończone i niemożliwe do dokończenia; uświadomienie sobie, że najbardziej obiecujące i najlepsze do obrony cele nauczania znajdujemy w powiązaniu z tym większym przedsięwzięciem; samokrytyczna obserwacja; przeświadczenie, że samo nauczanie jest formą ponownego uczenia się wespół z innymi, gdzie nauczyciel występuje w roli słuchacza, pytającego, instruktora, przewodnika oraz odpowiedzialnego i zatroskanego przywódcy; świadomość, że różnice w zdolnościach oraz w poczuciu tożsamości zarówno komplikują, jak i ubogacają to, co rozumiemy jako słuszność i stosowność w doświadczeniu edukacyjnym; docenienie faktu, że w prawdziwej społeczności uczących się powstaje spontanicznie specyficzny etos; krytyczna świadomość, że wiedza, rozumiana jako apodyktyczne mistrzostwo albo indywidualistyczna władza, albo zręczny przymus, działa zakulisowo, podważając ten etos. To tylko wstępny szkic niektórych dyspozycji do działania albo cnót praktycznych, które mogą wyróżniać nauczanie jako praktykę. Niech on posłuży do pokazania, że to, co nazywamy „umiejętnościami”, ,zwyczajami”, a nawet „metodami”, przynależy do nauczania w sposób bardziej zawiły niż się zwykło uważać, używając tych terminów. 


\section{Zakończenie}

Podsumowując, nie trzeba podkreślać, że próba doświadczenia nauczania jako sposobu życia oznacza podjęcie powracającej, a wręcz ciągłej walki - walki między wyższymi formami ludzkiej wolności a wpływami, które nieustannie zagrażają tej wolności przez jawne lub subtelne formy zniewolenia. Sukces w tej walce to nie sprawa być albo nie być. To raczej sprawa stopnia czy też jego wahań.

Nauczanie jako sposób życia nie jest więc ani świętością, ani prześladowaniem, choć musi przechodzić przez momenty błogosławionego natchnienia i piekielnego zamętu. Nie należy go też mylić z ascetyzmem czy kapłaństwem, które właściwie postrzega się jako powołanie. Jest ono raczej specyficznie konwersacyjnym sposobem bycia człowiekiem w świecie, który jest ,ludzki, zbyt ludzki”, jak to ujął Nietzsche; w świecie, który byłby pozbawiony czegoś bardzo cennego, gdyby zabrakło w nim tego sposobu życia, nad którym zastanawialiśmy się, i tych przekonań, które go zainspirowały.

tlumaczył z języka angielskiego Michał Mejer

\section{TEACHING AND LEARNING AS A WAY OF LIFE}

\section{Abstract}

This essay seeks to show that teaching and learning should be properly understood not as a project carried out according to the will of a higher power or party, but as a way of life with self-integrity arising from its own integral purposes. Thus the essay seeks to provide an understanding of educational practice and educational thought which contrasts in key respects with that by Alasdair MacIntyre's, though it also have some notable parallels. A largely forgotten 'Socrates of Athens' is identified as furnishing the original inspirations for the understanding of education explored in the essay. Some influential modern (and postmodern) negations of this understanding are then reviewed. Arising from its investigation of teaching and learning as a singular kind of relationship, 
the essay concludes with a brief sketch of some virtues that might constitute the way of life in question in its more active and its more reflective moments.

Key words: pedeutology, philosophy of education, liberalism.

Pádraig Hogan - emerytowany profesor pedagogiki na Wydziale Edukacji w National University of Ireland w Maynooth. Były przewodniczący Educational Studies Association of Ireland i były redaktor naczelny periodyku wydawanego przez to stowarzyszenie - „Irish Educational Studies”. Członek redakcji „Journal of Philosophy of Education”. Wybrane publikacje: The Custody and Courtship of Experience (1995), The Future of Religion in Irish Education (1999), Education and Practice (2004). Adres korespondencyjny: Education Department, NUI Maynooth, Co Kildare, Ireland. E-mail: padraig.hogan@, nuim.ie 